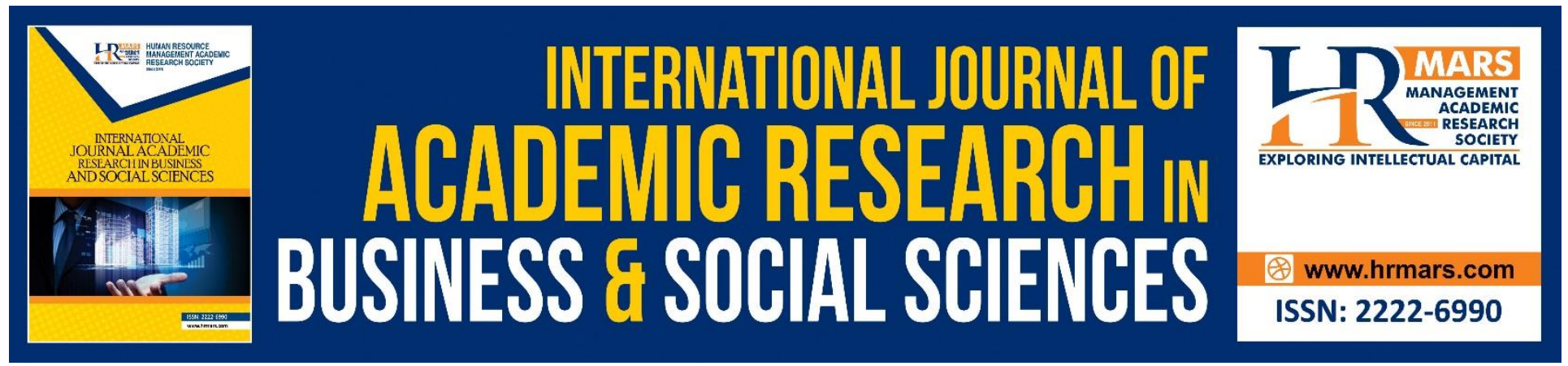

\title{
Management of Construction Safety: The Failure and Success of Stakeholders
}

\begin{abstract}
Samuel Opeyemi Williams, Razali Adul Hamid, Mohd Saidin Misnan, Benson Akintoye Ogunbode
\end{abstract}

To Link this Article: http://dx.doi.org/10.6007/IJARBSS/v8-i9/4549

DOI: $10.6007 /$ IJARBSS/v8-i9/4549

Received: 07 August 2018, Revised: 26 August 2018, Accepted: 19 Sept 2018

Published Online: 28 September 2018

In-Text Citation: (Williams, Hamid, Misnan, \& Ogunbode, 2018)

To Cite this Article: Williams, S. O., Hamid, R. A., Misnan, M. S., \& Ogunbode, B. A. (2018). Management of Construction Safety: The Failure and Success of Stakeholders. International Journal of Academic Research in Business and Social Sciences, 8(9), 58-68.

\section{Copyright: (C) 2018 The Author(s)}

Published by Human Resource Management Academic Research Society (www.hrmars.com)

This article is published under the Creative Commons Attribution (CC BY 4.0) license. Anyone may reproduce, distribute, translate and create derivative works of this article (for both commercial and non-commercial purposes), subject to full attribution to the original publication and authors. The full terms of this license may be seen at: http://creativecommons.org/licences/by/4.0/legalcode

\section{Vol. 8, No. 9, September 2018, Pg. 58 - 68}

Full Terms \& Conditions of access and use can be found at http://hrmars.com/index.php/pages/detail/publication-ethics 


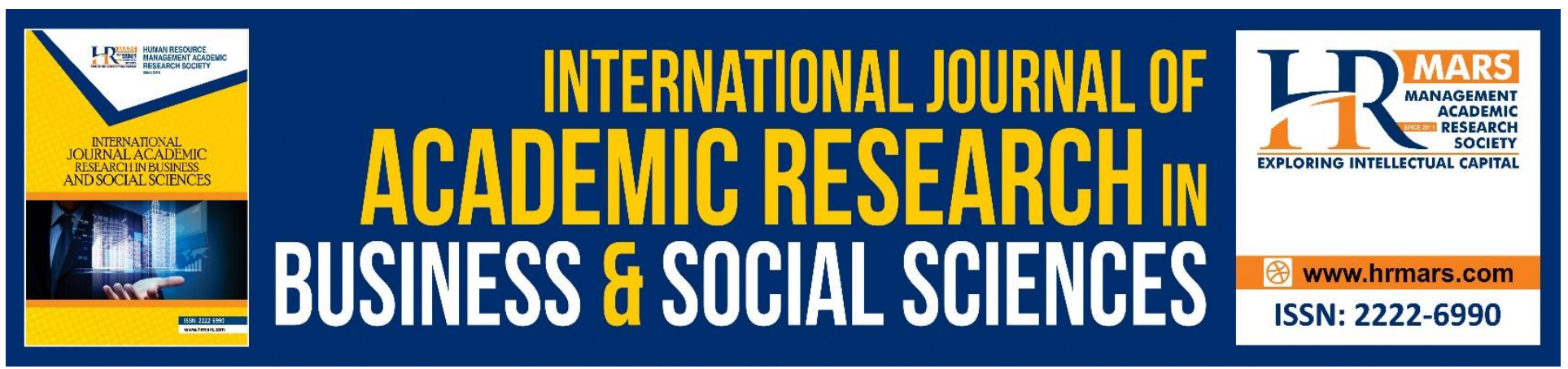

\title{
Management of Construction Safety: The Failure and Success of Stakeholders
}

\author{
Samuel Opeyemi Williams ${ }^{1}$, Razali Adul Hamid², Mohd Saidin \\ Misnan ${ }^{3}$, Benson Akintoye Ogunbode ${ }^{4}$ \\ 1,2,3 Department of Quantity Surveying, Faculty of Built Environment and Surveying, \\ Universiti Teknologi Malaysia, Johor, Malaysia. \\ ${ }^{1,4}$ Department of Quantity Surveying, Faculty of Environmental Studies, \\ Rufus Giwa Polytechnic, Owo, Ondo State, Nigeria.
}

\begin{abstract}
At global level, the building construction sites are unsafe, Nigeria in particular. Site operatives are unprotected against risk. Fall, slip, trip, struck-by, and electric shock are predominant accidents on the building construction sites, while stakeholders are only engrossed with passion for cost, quality and timely delivery of project. Consequent upon the persistent accident occurrence on the building construction sites, the study aimed at revealing the failures of construction stakeholders in the effective management of construction safety. In achieving this, an extensive literature review was engaged, which exposes a copious number of factors responsible for accident as a result of failure on the part of the construction stakeholders. Establishing the causes of these accidents is paramount, as it serves as a precursor to unveiling the playable roles by the stakeholders in mitigating accident occurrence on building construction sites. Consequently, the study unearths the success factors for effective management of safety on construction sites which are inclusive of: consultants awarding contracts to contractors with good safety records, contractors enforcing the use of safety items and compliance of workers with safety regulations, giving necessary reports on safety issues, organising safety training, setting up safety committee, and embarking on thorough safety inspection and supervision. Finally, the client should ensure that enough funds are devoted to safety of workers as well as engaging competent and safety conscious professionals in building project.
\end{abstract}

Keywords: Accident, Construction Stakeholders, Hazards, Operatives, Safety.

\section{Introduction}

Unparalleled is the contribution of construction industry to national development, as the industry is known to be dynamic in nature. An attention cannot be drawn away from Tanko et al. (2017), Agwu \& Olele (2014) as well as Hosseinian \& Torghabeh (2012) who commented on the positive contribution of the construction industry towards national development in most countries. Besides, according to 
INTERNATIONAL JOURNAL OF ACADEMIC RESEARCH IN BUSINESS AND SOCIAL SCIENCES Vol. 8, No. 9, Sept. 2018, E-ISSN: 2222-6990 @ 2018 HRMARS

Tanko et al. (2017), 4.18\% was the share of the construction industry in the Gross National Product of 2015 in Nigeria. The industry is, however, characterized by lots of mishaps on construction sites, with an attendant consequence of loss of limbs, resource wastage, damaged equipment, works interruption, extended project duration, and daily records of untimely death of workers.

Nevertheless, effort to refute the facts on the existence of accidents on construction sites is beyond any accomplishment, as nearly every site is predominantly concluded to be unsafe as a result of the nature of activities executed, faulty designs, exposure to adverse weather (Aniekwu, 2007), confinement of operations, untrained operatives (Toole, 2002), unsupervised workers (Abdul Rahim et al., 2008), engagement of defective equipment (Edwards \& Nicholas, 2002), usage of unsafe materials, and the like. Besides, deaths, hazards (Tahir et al., 2008), risks, and disability are common syndrome on building construction sites (BCS), leaving no country aside. Moreover, the victims (operatives) of accident experience injuries, as well as loss of incomes. Further information confirmed that accidents in workplaces, as well as illnesses cost the world a neighbourhood of US \$2.8 Trillion annually (Abubakar, 2015; Asanka \& Ranasinghe, 2015). It is, however, beyond any disputation that the industry is characterised with tight schedule of short targeted project duration, and unpalatable working environment as a result of activities carried out in open space (Orji et al., 2016). However, going by ranking, in relation to dangerous activities and fatalities, the industry polls third, queuing behind mining and fishing industries (Udo et al., 2016; Wikipedia, 2015), though it is still argued out that accidents are part and parcel of construction industry (Sejas, 2014). To be digested is the fact that a good number of accidents occur on BCS at different times to different persons, while some of these accidents are falls-from-height (Fass et al., 2015, Zhang et al., 2015), electrical hazards (HSE, 2006), collapse of structure (Ede, 2010), vehicle-related (Radmin, 2017), slip and trip (Asanka \& Ranasinghe, 2015), and contact with objects (Orji et al., 2016), while it is undoubtedly confirmed that many other industries are part of this mishap (Carrillo-Castrillo et al., 2013; Liang et al., 2011; Joint Commission, 2008; Smith \& Program, 2002).

\section{The Global Situation of Safety and Health}

Controversial issues have bedeviled the situation of health and safety at global level, particularly the rate of occurrence of accident, as some scholars argue that it is declining, while some believe that it keeps rising. However, to Wong et al. (2016), improvement of safety was recorded and reported by taking a cursory look at three countries viz; Hong Kong (HK), United Kingdom (UK) and United States (US). The three countries experience a decline in accident rate, as Hong Kong (HK) in 2000 to 2002, and 2010 to 2012 had an accident rate of 14.98\%, 11.46\%, 8.52\%, 5.21\%, 4.97\% and $4.43 \%$ respectively. By examining UK safety situation, the rate of accident between 2004/2005 and $2012 / 2013$ was $0.25 \%$ and $0.15 \%$ respectively. Moreover, without overlooking that of US (nonfatal accident), the trend was declining from 8.3\%, through to 3.7\% (2000-2012), all facts being indicated in Table 1 below. Nevertheless, Kadiri et al. (2014) and Orji et al. (2016) corroborated Occupational Safety and Health Administration (2005) to belief that the global rate of fatal accident on construction sites was 60,000, while the actual rate of occurrence of accident is unknown in Nigeria (Udo et al., 2016; Agwu \& Olele, 2014; Ehi, 2010) as a result of non-responsive attitude of the contractors in reporting accident (Diugwu et al., 2012; Idoro, 2011). 
INTERNATIONAL JOURNAL OF ACADEMIC RESEARCH IN BUSINESS AND SOCIAL SCIENCES Vol. 8, No. 9, Sept. 2018, E-ISSN: 2222-6990 @ 2018 HRMARS

Table 1: Showing the Rate of Occurrence of Accident in HK, UK, and US.

\begin{tabular}{|c|c|c|c|c|c|c|c|c|}
\hline \multicolumn{3}{|c|}{ HONG KONG } & \multicolumn{3}{|c|}{ UNITED KINGDOM } & \multicolumn{3}{|c|}{ UNITED STATES } \\
\hline Year & $\begin{array}{c}\text { Rate of } \\
\text { occurrence } \\
(\%)\end{array}$ & $\begin{array}{c}\text { Reduction } \\
(\%)\end{array}$ & Year & $\begin{array}{c}\text { Rate of } \\
\text { occurrence } \\
(\%)\end{array}$ & $\begin{array}{c}\text { Reduction } \\
(\%)\end{array}$ & Year & $\begin{array}{c}\text { Rate of } \\
\text { occurrence } \\
(\%)\end{array}$ & $\begin{array}{c}\text { Reduction } \\
(\%)\end{array}$ \\
\hline \multicolumn{3}{|c|}{ All Accidents } & \multicolumn{3}{|c|}{ Major Injuries } & \multicolumn{3}{|c|}{ Non-Fatal Accident } \\
\hline 2000 & 14.98 & - & $2004 / 2005$ & 0.25 & - & 2000 & 8.3 & - \\
\hline 2001 & 11.46 & 3.52 & $2012 / 2013$ & 0.15 & 0.10 & 2001 & 7.9 & 0.4 \\
\hline 2002 & 8.52 & 2.94 & & & & 2002 & 7.1 & 0.8 \\
\hline & \multicolumn{8}{|c|}{ Non-Major Injuries } \\
\hline 2010 & 5.21 & 3.31 & $2004 / 2005$ & 0.5 & - & 2010 & 4.0 & 3.1 \\
\hline 2011 & 4.97 & 0.24 & $2011 / 2012$ & 0.4 & 0.10 & 2011 & 3.9 & 0.1 \\
\hline 2012 & 4.43 & 0.545 & & & & 2012 & 3.7 & 0.2 \\
\hline
\end{tabular}

\section{Safety Situation in Nigeria Construction industry}

Countless number of safety researchers had dealt with health and safety (H\&S) issues, with Nigerian scholars not left behind in this scenario, but the failures and successes of the construction stakeholders (client, consultant, contractor) are infinitesimally given an attention, thereby creating a gap that will be holistically filled in this research. However, a high level of cognizance is expected to be attached to the current situation of H\&S in Nigeria for better declaration of playable roles of the stakeholders. Consequently, Idoro (2008) assessed the stakeholders as being negligent and unconcerned, and such action which is coupled with the availability of deficient statutory regulations, unavailable medical facilities and training programs (for staff and operatives), and absence of safety information. In addition to these are the clear evidences of exposures of workers to hazards and unsafe environment on the site. It is a serious issue, and very pathetic, as workers are seen carrying out activities on site without strict compliance with safety regulations, which Umeokafor et al. (2014) rated the level of compliance as very low, though with so many reasons (higher profit margin, inadequacy of fund and staff, management commitment, stakeholders' perception) given for non-compliance. Besides, the Inspectorate Division of the Federal Ministry of Labour and Employment who should have served as manager of occupational H\&S and an enforcer of the regulations are found deficient and ineffective (Abubakar, 2015). Further steps were taken by Idoro (2008) in tracing out the origins of the adopted regulations in Nigeria, which were found to be extractions of United Kingdom (UK) and United States (US), and moreover the adopted Factories Act of 1990 is without the inclusion of the construction industry. By drawing from past studies in relation to $\mathrm{Nigeria,} \mathrm{H \& S}$ risk management capability is rarely an important factor for considering contractors' worthiness (Olatunji \& Aje, 2005), accident is prominent at the Nigerian building construction sites (Muhammad et al., 2015), there is lack of effective statutory regulations on H\&S (Idoro, 2008), there is non-availability of accurate records (Muhammad et al., 2015; Idoro, 2008), contractors are not complying with $\mathrm{H} / \mathrm{S}$ regulations on sites (Muhammad et al., 2015), construction stakeholders see implementation of H\&S as an additional cost (Okoye \& Okolie, 2014), the management of OSH via the Ministry of Labour and Employment (Inspectorate division) is ineffective, and stakeholders show lack of concern for safety (Udo et al., 2016). Furthermore, it is disheartening to see that impact of accident is much on the client (delayed project), contractors (increase in project cost), and workers (injuries, loss of lives and income) (Diugwu et al., 2015; Udo et al., 2012; Mthalane et al., 2008). In relation to Ehi (2010), it was equally stated that workers are 
INTERNATIONAL JOURNAL OF ACADEMIC RESEARCH IN BUSINESS AND SOCIAL SCIENCES

Vol. 8, No. 9, Sept. 2018, E-ISSN: 2222-6990 @ 2018 HRMARS

dying and sustaining injuries on daily basis, work places have become death traps, and loss of loved ones to occupational accidents is increasingly high in Nigeria.

\section{Problem Statement}

There is a persistent occurrence of accident on the BCS in Nigeria. Stakeholders are less concerned about safety, as cost, timely delivery and quality are prioritised, while safety is compromised. Therefore, there is need to exhume the major factors responsible for these accidents in reference to the failures on the part of the construction stakeholders, with an attendant exposition of their roles and responsibilities in ensuring safety so as to experience zero-accident on the sites.

\section{Materials and Methods}

The research is aimed at exploring the factors responsible for lack of safety on BCS in relation to the failure of the stakeholders, while the identified factors were subsequently discussed accordingly to see how the failures of the stakeholders adversely impact construction safety. The identified factors were explored through an extensive literature review of safety-related articles, and the subsequent discourse gave an insight to the extent at which the failures of the construction stakeholders create an unsafe situation on the building construction sites. The significant roles played by the stakeholders are explicitly indicated in relation to fostering safety on building construction site, which has a plausible impact on prevention of accidents.

\section{Discussion}

Having critically considered the situation of safety management in relation to Nigerian building construction sites, the failures of the stakeholders should be given an extensive discourse, as they play major roles in subjecting construction sites to hazardous conditions. Consequent upon the fact that understanding the causes of accident precedes the preventive measures (Suraji et al., 2001), a plethora of scholars has given an un-obscured insight to the distal and proximate factors underpinning the unsafe situation on the BCS. For space and time, a few numbers of the authors are mentioned in this research. However, lack of organizational commitment (Kemei et al., 2015), lack of enforcement of safety regulations (Kemei et al., 2015), non-availability of H\&S file to the contractor, deficient enforcement of safety standards (Lubega et al., 2000), poor safety consciousness (Kadiri et al., 2014), inefficiencies in project planning (Palaniappan et al., 2007) and appointment of inexperienced project managers (Williams et al., 2018) are all attributed to the client. All these failures have given rise to accident on the BCS, as the lives of the workers are exposed to unnecessary hazards in the handling of operations on site. Besides, the acceleration of design and project construction, which is orchestrated by the client, is another major factor. Furthermore, bad building designs, inadequate designs, and faulty designs (Leo, 2014), specification of poor quality building materials (Palaniappan et al., 2007), and failure to supply sufficient information (Hawksley, 1999) are all having a link with the consultants. In addition, the contractor, who is the employer of the construction operatives, is equally bedevilled with failure in maintaining safety on the BCS. It is crystal clear that the contractors engage uncertified skilled labour (Kolo, 2009), assign job to untrained workers (Kemei et al., 2015), employ incompetent personnel (Lubega et al., 2000), avoid training of workers (Toole, 2002), refute the provision of PPE and technical guidance (Kemei et al., 2015), make no provision for first aid measures, skip operational procedures (Harms-Ringdahl, 2013; Abdul Rahim, 2008), jettison safety devices (Carrillo-Castrillo et al., 2013), and lack innovative technology on safety measures (Ali \& Kamaruzzaman, 2010; Tam et al., 2004). By taking a clue from Kemei et al. (2015), 
INTERNATIONAL JOURNAL OF ACADEMIC RESEARCH IN BUSINESS AND SOCIAL SCIENCES Vol. 8, No. 9, Sept. 2018, E-ISSN: 2222-6990 @ 2018 HRMARS

the contractors are found to be deficient in making provision for safety management manuals and safety information, while also ineffective operation of safety regulations (Abdul-Rahim, 2008), improper supervision, lack of concern for safety matters, misinterpretation of working plan and detail drawings are common occurrences in respect of construction safety.

Consequently, the employer (client), being the initiator of the project, possesses the charismatic ability to have the project influenced in a safe way, so onus is on him to give all that is required to enforce safety throughout the period of design and construction. This can be achieved by ensuring that appointment of vibrant and experienced professionals possessed with safety consciousness is given a priority. He should ensure effective project planning, enforcement of safety regulations, adequate budgeting for health and safety (H\&S) issues, effective supervision through his consultants and allows sufficient time for the designers and the constructor in carrying out their functions. Moreover, the client is expected to be involved in safety committee activities and safety meetings, appointment of safety expert at the design phase (e.g. CDM coordinator in UK), ensuring that H\&S related issues are not brought under the umbrella of compromise, as well as putting in place $H \& S$ considerations at the design stage by devoting much funds for safety issues. Furthermore, the consultants are significantly capable in ensuring safety on the site through: production of safe design, and specification of good quality building materials, provision of adequate working drawings, ensuring devotion of enough funds by the client for $\mathrm{H} \& \mathrm{~S}$, and reaching an agreement with the client on the H\&S terms, ensuring that the contractors maximally utilise the H\&S funds, communicating safety information to the contractors, and participating in inspection, supervision, and safety meetings. They should also ensure that the contractors and subcontractors comply with safety regulations. However, in relation to the contractors, they have major roles to play in the management of safety on the BCS, being the employers of labour. With regards to Heinrich et al. (1980) and Hosseinian \& Torghabeh (2012), the management's input is indispensable in the prevention of accident on the BCS. The contractor, as the manager of the organisation, possesses the capacity to do and undo (action or inaction) in respect to the H\&S related issues on the BCS. If other stakeholders fulfill their responsibilities in ensuring safety, but there still exists refusal or failure on the part of the contractor in complying with safety regulations, then the site still remains unsafe and lives of workers will not be protected against dangers. Therefore, the contractor is responsible for employing and engaging skilled workers, ensuring proper and adequate supervision, showing commitment to safety of workers, enforcement of compliance of workers with safety regulations, provision of and ensuring the usage of safety items, barricading the site (including working areas) against unauthorised access, conducting safety training for supervisors and workers, reporting of accident and investigation to prevent reoccurrence, identification of potential hazards, carrying out safety related program/activities (safety committee, campaign, meeting), and giving rewards to workers with good safety performance. Additionally, there should be provision of welfare/medical facilities, illumination where necessary, and warning signs at conspicuous places in bilingual language, while they should equally ensure proper channel of communication of information to workers.

In addition, crystal-clear evidences avail that project participants' error or failure (action and inaction) impacts safety of workers on BCS. However, in the early section, it was depicted that exhuming the causes of accident precedes the formulation of preventive strategies. The employer 
INTERNATIONAL JOURNAL OF ACADEMIC RESEARCH IN BUSINESS AND SOCIAL SCIENCES Vol. 8, No. 9, Sept. 2018, E-ISSN: 2222-6990 @ 2018 HRMARS

(building owner) is glimpsed to be among the accident causative stakeholders. However, by addressing these adverse situations in a positive way will make the client excluded from the bad records of safety deficiency. For the consultants, most especially the designers, the inadequacies as well as unsafe and bad designs are majorly a confronting challenge to safety in the industry. Moreover, ancient and contemporary belief is that the designers are aesthetically engrossed at the expense of safety and cost, whereas inherent hazards can be eliminated at the design table, and it is expected that safety information should be well communicated to the contractor. However, clamouring for safety on site should not be a hammer and a wedge on the heads of contractors and workers alone, but also on the professionals (consultants), of which the safety consciousness will enable a safe design to be put up, while it is necessary for these consultants to also submit themselves to safety training. Additionally, their involvement in inspection of site, risk identification and close supervision (i.e. designer's representative) should not be compromised nor jettisoned. Furthermore, the contractor could be significantly concluded to be responsible for the unsafe conditions of the site, thereby subjecting lives of the workers to adverse situations, because of his lack of safety commitment. Most contractors are very economical when it comes to cost, that is, minimisation of cost and maximisation of profit, all being done at the expense of the safety of construction workers. Thus, the efforts of the contractors by making all safety items available for the workers, proper maintenance of equipment, and the employment of safety conscious and experienced workers are not to be viewed as strange, because these are his responsibilities in any contract, since the cost covering safety issues and other things are included in the contract documents (BOQs). Leaving aside the key stakeholders, the operatives are in the center of the drive to foster safety on site, as they are the real victims when accident occurs. To some workers, safety may not matter so much to them when it comes to benefit that will be accrued to them. They joyfully undertake overtime work, and engage in emergency work as a result of the promised bonus or rewards. Nevertheless, their employer needs enforcement hammer to hit the nails of compliance with safety regulations on their heads, as the occurrence of accident delays project execution, destroys equipment, discredits the company, and also brings attendant increase in the cost of construction to the contractor, to mention a few. Hence, the necessity of harnessing themselves with PPE should be enforced on the workers. Though, there have been complaints that they feel inconvenient when working with these safety items.

\section{Conclusion}

The research has found out the laxity on the sides of the construction stakeholders (client, consultant, and contractor) in the management of safety on the site. Such laxities which are inclusive of failure in making available safety funds by the client, production of unsafe designs by the consultants, lack of enforcement of safety regulations by the contractors, and failures of the workers in harnessing themselves with PPE, and the like. Moreover, multifarious functions of the stakeholders were equally spelt out in order to achieve effective management of safety. Thus, safety is of paramount importance in all human endeavours, and the liability for the prevention of BCS accident lies in the hands of the construction stakeholders. Therefore, for a sustainable H\&S performance in the construction industry, pro-active measures/steps are needed to be taken which are the remits of the key stakeholders of the industry, government inclusive. Consequently, the research recommends the understated facts, in order to prevent the further occurrence of accident on the BCS. 
INTERNATIONAL JOURNAL OF ACADEMIC RESEARCH IN BUSINESS AND SOCIAL SCIENCES Vol. 8, No. 9, Sept. 2018, E-ISSN: 2222-6990 @ 2018 HRMARS

The contractors must hold primary responsibility for OHS matters, by providing all necessary safety items, coupled with the enforcement of their usage by the operatives.

The enforcement of compliance of workers with safety regulations lies within the capacity of the contractor, and must oblige to carry it out.

Contractors should produce safety reports of previously executed projects, as well as safety plans for the proposed project during tendering, while the contractors without good safety reports should be excused out of contract award.

Contractors are to make arrangement for their supervisors in attending safety conferences, while the safety professionals are requested to keep the registered contractors abreast of any conference anytime it holds.

Notice of commencement of all new projects should be brought to the OSH agency under the Federal Ministry of Labour and Employment to enable inspection of sites to be carried out. All incidents/accidents on site should be documented for onward transmission to the OSH agency for investigation in order to prevent reoccurrence.

It is expected by the client to devote much money for H\&S issues as well as appointing professionals of high competence who are safety conscious.

Conclusively, the consultants should display their professional ethic by awarding contracts to contractors of good safety records, while the construction workers who are the main victims of accidents are to maintain discipline during operations, harness themselves with safety items, observe enough rest, engage in teamwork, comply with safety regulations and avail themselves during training programme and the like. With the implementation of the recommendations above, injuries will be prevented, work will be carried out safely, loss of lives will be averted, construction works will be carried out uninterrupted, and project budget will be maintained.

\section{Acknowledgement}

The unflinching efforts of all the authors of this article are highly acknowledged, most especially the constructive contributions and supervisory roles of the second and third authors.

\section{Corresponding Author}

Opeyemi Samuel Williams,

Department of Quantity Surveying,

Faculty of Built Environment,

Universiti Teknologi Malaysia,

Johor, Malaysia

Email: yemiwilly2006@gmail.com

\section{References}

Abdul Hamid, A.R., Abdul Majid, M.Z., \& Singh, B. (2008). Causes of Accidents at Construction Sites. Malaysian Journal of Civil Engineering, 20(2): 242-259. Retrieved from https://www.researchgate.net/publication/46480600

Agwu, M. O., \& Olele, H. E. (2014). Fatalities in the Nigerian Construction Industry: A Case of Poor Safety Culture. British Journal of Economics, Management \& Trade, 4(3), 431-452. Retrieved from http://www.sciencedomain.org/abstract/2798

Aniekwu N. (2007). Accidents and Safety Violations in the Nigerian Construction Industry. Journal of 
INTERNATIONAL JOURNAL OF ACADEMIC RESEARCH IN BUSINESS AND SOCIAL SCIENCES Vol. 8, No. 9, Sept. 2018, E-ISSN: 2222-6990 @ 2018 HRMARS

Science and Technology, Vol. 27 (1). Retrieved from https://doi.org/10.4314/just.v27i1.33027 Asanka W.A. \& Ranasinghe M. (2015). Study on the Impact of Accidents on Construction Projects.

$6^{\text {th }}$ International Conference on Structural Engineering and Construction Management, Kandy, Sri Lanka, $11^{\text {th }}-13^{\text {th }}$ December. Retrieved from https://www.researchgate.net/publication/288022884

Carrillo-Castrillo, J. A., Rubio-romero, J. C., \& Onieva, L. (2013). Causation of Severe and Fatal Accidents in the Manufacturing Sector. International Journal of Occupational Safety and Ergonomics, 19(3), 423-434. Retrieved from https://doi.org/10.1080/10803548.2013.11076999

Diugwu, I. A., Baba, D. L., \& Egila, A. E. (2012). Effective Regulation and Level of Awareness: An Exposé of the Nigeria's Construction Industry. Open Journal of Safety Science and Technology, 2:140-146 doi:10.4236/ojsst.2012.24018. Retrieved from http://www.SciRP.org/journal/ojsst

Department of Occupational Health and Safety (DOSH)(2016). Fatal Accident Case. Retrieved frome http://www.dosh.gov.my/index.php. on Jan, 2017

Ede, N.A. (2010). Building Collapse in Nigeria: The Trend of Casualties the Last Decade (2000 2010). International Journal of Civil \& Environmental Engineering, Vol:10 No:06, pp32-36. Retrieved from https://core.ac.uk/download/pdf/18295260.pdf

Edwards, D. J., \& Nicholas, J. (2002). The State of Health and Safety in the UK Construction Industry with a Focus on Plant Operators. Structural Survey, Vol. 20 Iss 2, 78-87. Retrieved from https://doi.org/10.1108/02630800210433855

Ehi Iden (2010). The Absence of Occupational Health and Safety Laws in Nigeria. Occupational Health and Safety Managers (Nigeria). Retrieved from http://ohsmcomng.blogspot.my on 17 Jan, 2017.

Elufidipe O. (2009). The Prevention of Accidents on Building Construction Sites. International Journal of Insurance Policy, 10-15.

Fass S., Yousef R., Liginlal D., Vyas P. (2016). Understanding Causes of Fall and Struck-by Incidents: What Differentiates Construction Safety in the Arabian Gulf Region. Applied Ergonomics. Retrieved from https://www.sciencedirect.com/science/article/pii/S0003687016300898

Goh, K. C., Goh, H. H., Omar, M. F., Toh, T. C., \& Asuhaimi, A. (2016). Accidents Preventive Practice for High-Rise Construction. In MATEC Web of Conferences, 47(August), 3-8. Retrieved from https://doi.org/10.1051/matecconf/20164704004

Health and Safety Executive (HSE) (2006). Health and Safety in Construction. Health and Safety in Construction HSG150, 14. Retrieved from http://www.hse.gov.uk/pubns/priced/hsg150.pdf

Heinrich, H.W. (1931). Industrial Accident Prevention: A Scientific Approach, McGraw-Hill, New York.

Heinrich H.W., Peterson, D., \& Roos, N. (1980). Industrial Accident Prevention: A Safety Management Approach, Fifth Edition. McGraw-Hill, New York.

Hosseinian, S. S., \& Torghabeh, Z. J. (2012). Major Theories of Construction Accident Causation Models: A Literature Review. International Journal of Advances in Engineering \& 
INTERNATIONAL JOURNAL OF ACADEMIC RESEARCH IN BUSINESS AND SOCIAL SCIENCES Vol. 8, No. 9, Sept. 2018, E-ISSN: 2222-6990 @ 2018 HRMARS

Technology, 4(2), 53-66. Retrieved from https://www.scribd.com/document/307258645/

Idoro, G. I. (2011). Comparing Occupational Health and Safety (OHS) Management Efforts and Performance of Nigerian Construction Contractors. Journal of Construction in Developing Countries, 16(2), 151-173. Retrieved from http://web.usm.my/jcdc/vol16 2 2011/ART7 jcdc16-2.pdf

Idoro, G. I. (2008). Health and Safety Management Efforts as Correlates of Performance in the Nigerian Construction Industry. Journal of Civil Engineering and Management, 14: 277-285. Retrieved from https://doi.org/10.3846/1392-3730.2008.14.27

Kadiri Z.O., Nden T., Avre G.K., Oladipo T.O., Edom A., Samuel P.O., Ananso G.N. (2014). Causes and Effects of Accidents on Construction Sites (A Case Study of Some Selected Construction Firms in Abuja F.C.T Nigeria). IOSR Journal of Mechanical and Civil Engineering (IOSR-JMCE) e-ISSN: 2278-1684,-ISSN: 2320-334X, Volume 11, Issue 5 Ver. I. PP 66-72. Retrieved from http://www.iosrjournals.org/iosr-jmce/papers/vol11-issue5/Version-1/J011516672.pdf

Joint Commission (2008). Preventing Accidents and Injuries in the MRI Suite. American Radiological Nurses Association. Retrieved from https://doi.org/10.1016/j.jradnu.2008.04.002 Kemei, R.K., Kaluli, J.W., \& Kabubo, C.K. (2015). Assessment of Occupational Safety and Health in Construction Sites in Nairobi County, Kenya. Sustainable Materials Research and Technology Centre, JKUAT. Retrieved from https://doi.org/10.1016/i.proeng.2011.11.2425

Liang, K., Liu, J., \& Wang, C. (2011). The Coal Mine Accident Causation Model Based on the Hazard Theory. Procedia Engineering, 26, 2199-2205.55

Lubega, H. A., Kiggundu, B. M., \& Tindiwensi, D. (2000). An Investigation into the Causes of Accidents in the Construction Industry in Uganda. 2nd International Conference On Construction in Developing Countries: Challenges Facing the Construction Industry In Developing Countries, (2000), 1-12.

Retrieved from http://www.irbnet.de/daten/iconda/CIB8913.pdf

Mthalane, D., Othman, A. A. E \& Pearl, R. G., The Economic and Social impact of Site Accident on South African Society. CIDB Paper, No. 2005. https://www.researchgate.net/publication/271269767

Nkurunungi, W. J., (2005). Assessment of Safety of Workers at Building Sites in Uganda. Undergraduate Thesis, Department of Civil Engineering, Makerere University.

Retrieved from https://www.grin.com/document/213613

Orji Solomon E., Enebe Eucharia, C., \& Onoh, F. E. (2016). Accidents in Building Construction Sites in Nigeria: A Case of Enugu State. International Journal of Innovative Research and Development, 5(4), 244-248. Retrieved from www.ijird.com/index.php/ijird/article/download/90635/68250

Palaniappan, S., Sawhney, A., Janssen, M. A., \& Walsh, K. D. (2007). Modeling Construction Safety as an Agent-Based Emergent Phenomenon. In Automation and Robotics in Construction - Proceedings of the 24th International Symposium on Automation and Robotics in Construction (pp. 375-382). Retrieved from https://asu.pure.elsevier.com/en/publications/

Radmin (2017). Types of Construction Site Accidents. Construction Accidents Article. Retrieved from https://www.radlawfirm.com/types-construction-site-accidents/. on 16 April, 2017. 
INTERNATIONAL JOURNAL OF ACADEMIC RESEARCH IN BUSINESS AND SOCIAL SCIENCES Vol. 8, No. 9, Sept. 2018, E-ISSN: 2222-6990 (C) 2018 HRMARS

Sejas M. (2014). The Top 4 Causes of Safety Accidents. Ensafe Planning Solutions. Retrieved from www.lorman.com/resources/the-top-4-causes-of-construction-safety-accidents-14890

Smith, D. W., \& Program, E. S. (2002). US Agriculture Fatality Statistics. Extension Safety Program. Retrieved from http://agsafety.tamu.edu/files/2011/06/US-Agriculture-FatalityStatistics1.pdf

Suraji, A., Duff, A.R., and Peckitt, S. (2001). Development of Causal Model of Construction Accident Causation. Journal of Construction Engineering and Management /127(4), 337-344. Retrieved from https://doi.org/10.1061/(ASCE)0733-9364(2001)127:4(337)

Tanko L.B., Abdullah F. \& Ramly M.Z. (2017). Stakeholders Assessment of Constraints to Project Delivery in the Nigerian Construction Industry. International Journal of Built Environment and Sustainability. IJBES 4(1), 56-62. Retrieved from https://doi.org/10.11113/ijbes.v4.n1.160

Toole, T. M. (2002). Construction Site Safety Roles. Journal of Construction Engineering and Management, 128(3), 203-210. Retrieved from https://doi.org/10.1061/(ASCE)07339364(2002)128

Udo, U. E., Usip, E. E., \& Asuquo, C. F. (2016). Effect of Lack of Adequate Attention to Safety Measures on Construction Sites in Akwa Ibom State, Nigeria. Journal of Earth Sciences and Geotechnical Engineering, 6(1), 113-121. Retrieved from http://www.scienpress.com/Upload/GEO/Vol\%206 1 8.pdf

Zhang, S., Sulankivi, S., Kivinemi M., Romo, I., Eastman, C., \& Teizer, J. (2015). BIM-Based Fall Hazard Identification and Prevention in Construction Safety Planning. Safety Science 72 (2015)pp3145. Retrieved from https://www.sciencedirect.com/science/article/pii/S0925753514001829

Williams, O. S., Hamid A.R., \& Misnan M.S. (2018). Accident Causal Factors on the Building Construction Sites: A Review. International Journal of Built Environment and Sustainability. ljbes 5(1)/2018, 78-92 